\title{
Bioethanol Levels of Dragon Fruit (Hylocereus polyrhizus) Peel with the Addition of Blend Crude Cellulase Enzyme from Trichoderma reesei and Aspergillus niger
}

\section{Trianik Widyaningrum ${ }^{1,2 *}$, Masreza Parahadi ${ }^{3}$}

1) Department of Biology Education, Faculty of Teacher Training and Education, Ahmad Dahlan University, Kampus 4, Jl. Prof. Dr.Soepomo, Janturan, Yogyakarta 55164, Indonesia.

2) Department of Biology, Faculty of Mathematics and Natural Sciences, Brawijaya University, Gedung Biologi, Jl. Veteran, Malang 65145, Indonesia.

3) Department of Postgraduate Program in Biotechnology, Postgraduate School, Universitas Gadjah Mada, Jl. Teknika Utara, Barek Yogyakarta 55281, Indonesia.

Submitted: 05 December 2019; Accepted: 10 January 2020; Published: 15 April 2020

\begin{abstract}
The petroleum fuel crisis shows that Indonesia's fossil energy reserves are limited. It is necessary to develop an environmentally, friendly and sustainable alternative energy, one of which is bioethanol. This study aims to determine the bioethanol levels of dragon fruit (Hylocereus polyrbizus) peel with the treatment of cellulase enzymes from Trichoderma reesei and Aspergillus niger. This research was an experimental study that uses steps such as making dragon fruit peel substrate and filtrate, cellulose degradation with enzymes from Trichoderma reesei and Aspergillus niger and inoculating with yeast (Saccharomyces cerevisiae) with a fermentation time of 96 hours and then measured reducing sugar levels with the method of DNS, distillation, and the measurement of bioethanol levels using alcohol meters. The results have shown that using enzymes from Trichoderma reesei and Aspergillus niger can increase the reduction of $49.68 \%$ sugar levels in the treatment of T.reesei: A.niger (3: 1) and produce the highest bioethanol level, which is 2.46 $\%$ in the treatment of T.reesei: A.niger (2: 1)
\end{abstract}

Keywords: Aspergillus niger, dragon fruit peel, cellulase, Trichoderma reesei

The increasing demand for ethanol for various industrial purposes such as alternative sources of energy, industrial solvents, cleansing agents and preservatives has necessitated increased production of this alcohol (Ali et al., 2011). In the current time, the importance of alternative energy sources has become even more necessary not only due to the continuous depletion of limited fossil fuel stock but also for a safe and better environment. With an inevitable depletion of the world's energy supply, there has been an increasing worldwide interest in alternative sources of energy (Lynd et al., 2017; Chandel et al. 2007; Wyman, 1999; Herrera 2004; Herrera, 2006; Lin, 2006; Vertes \& Inui, 2006; Schubert, 2006; Dien, 2003).

\section{*Corresponding author}

Tel.: +62 816682123

Email: trianikwidyaningrum@pbio.uad.ac.id

(C) 2020, J. Tropical Biodiversity Biotechnology (CC BY-SA 4.0)
Currently, biomass-derived ethanol is produced at an industrial scale from sucrose and starch; however, this poses concerns about the potential competition with food and feed supplies (Hahn-Hägerdal et.al, 2006; Field, Campbell, J. E., \& Lobell, 2008). Hence, other alternatives such as the production on fallow fields of crops and grasses to produce biofuels have recently attracted attention. In particular, the lignocellulosic materials such as agricultural wastes are considered to be the main potential sources of biomass for "second generation" bioethanol production ( $\mathrm{Hu}$., e t al., 2008 ; Hahn-Hägerdal et al., 2006 ; Sakai et al, 2007; Merino \& Cherry, 2007; Goh et al, 2010 ).

Bioethanol is one of the renewable alternative fuels that have the potential to be developed in Indonesia. Bioethanol is produced from biomass fermentation processes aided by microorganisms. 
The requirement to make bioethanol is a biological material that has sugar content (glucose, starch, and fibre) (Hambali et al, 2007) among other is dragon fruit peel. Dragon fruit including cactus or Cactaceae family, red dragon fruit peel contains sugar component around $8.4 \%$ and also other complex carbohydrates like cellulose around 68.3\% (Jamilah et al., 2011).

Table 1. Sugar levels of Dragon fruit peel after treatment of T.reesei and A.niger

\begin{tabular}{ll}
\hline $\begin{array}{l}\text { Cellulase ratio between } \\
\boldsymbol{T} \text {. reesei and } \boldsymbol{A} \text {. niger }\end{array}$ & Sugar level $(\mathrm{mg} / \mathrm{mL})$ \\
\hline Control & $49.41 \pm 3.94^{\mathrm{a}}$ \\
$1: 0$ & $94.31 \pm 3.5^{\mathrm{de}}$ \\
$0: 1$ & $91.25 \pm 2.2^{\mathrm{d}}$ \\
$1: 1$ & $73.60 \pm 1.72^{\mathrm{b}}$ \\
$2: 1$ & $96.95 \pm 4.98^{\mathrm{de}}$ \\
$1: 2$ & $84.44 \pm 4.69^{\mathrm{c}}$ \\
$3: 1$ & $98.20 \pm 2.83^{\mathrm{e}}$ \\
$1: 3$ & $76.66 \pm 3.56^{\mathrm{b}}$ \\
\hline
\end{tabular}

The same letter within each row do not differ significantly $(p>$ $0.05)$ according to the Duncan test.

The cellulose degradation process can be done chemically or biologically using cellulolytic organisms originate from bacteria or fungi, degradation of cellulose into simpler sugars in the form of both cellobiose and glucose with the help of a catalyst. Hydrolysis can be carried out chemically (acid) or enzymatically, enzymatic hydrolysis using cellulase enzymes. Cellulase enzymes can be produced from cellulolytic microbes both mold and bacteria, while molds commonly used from Trichoderma and Aspergillus. Trichoderma reesei has been widely used for the production of commercial cellulase (Vandana and
Anahit, 2014). Cellulase is a multi-component enzyme comprising of endoglucanase, which attacks cellulose in the amorphous zone and releases oligomers such as cellobiohydrolase, that liberate cellobiose from reducing and non-reducing ends also $\beta$-glucosidase, which hydrolyze cellobiose to glucose and play a key role in avoiding cellobiose inhibition and thus enhancing the hydrolysis rates of cellulose into glucose (David, 2008; Mehdi et al, 2010; Sunkyu et al., 2010; Baljit, 2014; Veeresh and Wu, 2014). Aspergillus niger produces an enzyme that plays a role in accelerating the conversion of cellobiose to glucose, the enzyme $\beta$-glucosidase (Juhasz et al., 2003). The combination of cellulase enzymes from $T$. reesai and $A$. niger can be expected to increase the change of cellulose into glucose which is a material for making bioethanol.

This study aims to determine the levels of bioethanol dragon fruit peel (Hylocereus polyrbizus) with the treatment of cellulase enzymes from Trichoderma reesei and Aspergillus niger.

Dragon fruit peels were obtained from a local market in Indonesia. For analytical purposes, the Dragon fruit peels were made powder. Trichoderma reesei and Aspergillus niger culture were obtained from The Food \& Nutrition Culture Collection (FNCC), Food and Nutrition Centre, Universitas Gadjah Mada. The strains were maintained on PDA and incubated at room temperature for seven days. (Safaria et al., 2013).

A total of $5 \mathrm{~g}$ of Dragon fruit peel powder were put into Erlenmeyer $250 \mathrm{~mL}$ and added $25 \mathrm{~mL}$ nutrition solutions which every $1000 \mathrm{~mL}$ contains 1.0 g yeast extract, $1.5 \mathrm{~g}$ peptone, $1.4 \mathrm{~g}\left(\mathrm{NH}_{4}\right)_{2} \mathrm{SO}_{4}$; $2.0 \mathrm{~g} \mathrm{KH}_{2} \mathrm{PO}_{4}, 0.005 \mathrm{~g} \mathrm{FeSO}_{4} \bullet 7 \mathrm{H}_{2} \mathrm{O}, 5 \mathrm{~mL}$ solution CMC 1\%. The flasks were sterilized for 15 minutes at $121^{\circ} \mathrm{C}$. Two milliliters of spores (107-108 spores/ $\mathrm{mL}$ ) were inoculated and incubates at room

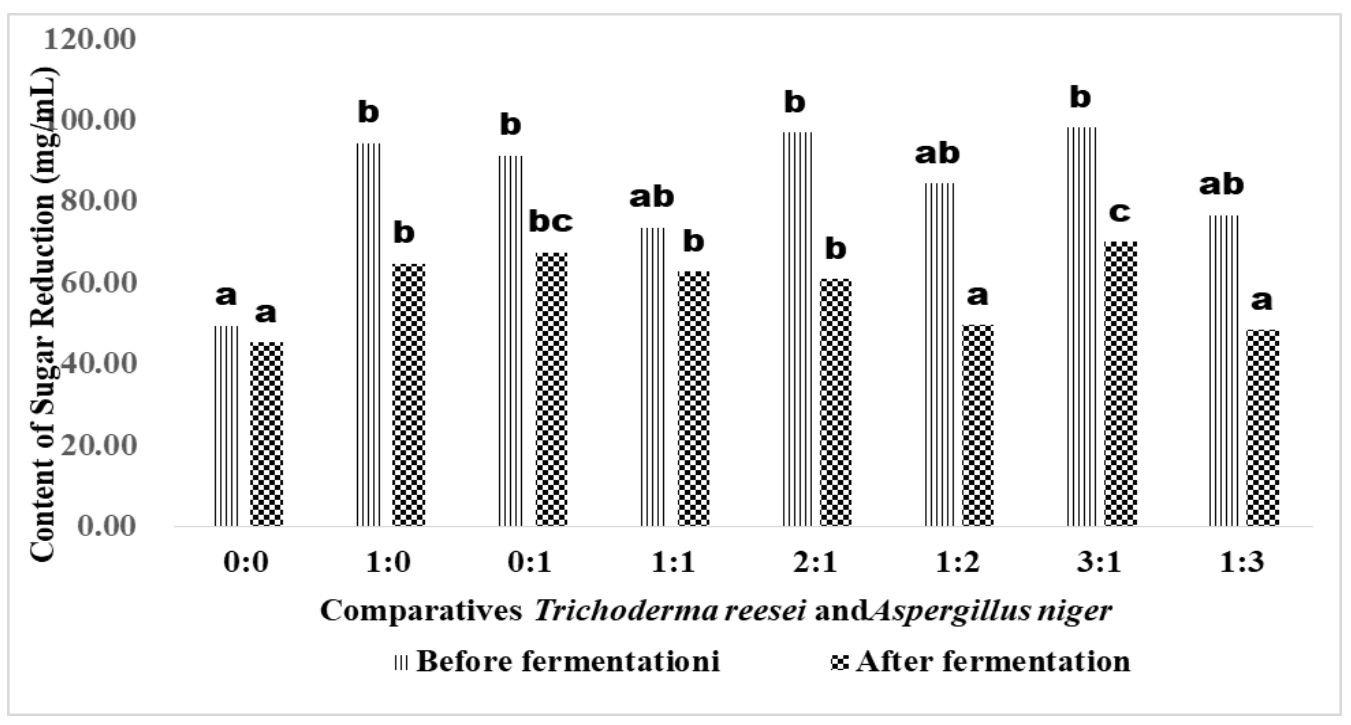

Figure 1. Reduced sugar levels before and after the treatment with Saccharomyces cerevisiae 
temperature and static condition, for 6 days for Trichoderma reesei and 8 days for Aspergillus niger (Sri Winarsih et al., 2014).

Tween $800.1 \%$ solution was taken $100 \mathrm{~mL}$ and poured into the dragon fruit peel sample then stirred at $150 \mathrm{rpm}$ for 120 minutes at room temperature. The solution was then centrifuged at $3000 \mathrm{rpm}$ for 10 minutes. The supernatant obtained was used as a crude enzyme extract (Szendefy et al., 2006).

Dragon fruit peel porridge put into Erlenmeyer $100 \mathrm{~mL}$ then added the crude enzymes T.reesei and A.niger were added as much as 10\% each according to the treatment with variations of $1: 0,0$ : 1, 1: 1, 2: 1, 1:2, 3: 1, 1: 3 using a measuring pipette aseptically and made three replications (21 Erlenmeyer), then stirred using a sterile glass stirrer. Erlenmeyer was covered with sterile cotton and coated with aluminum foil then incubated for 24 hours using an incubator at $37{ }^{\circ} \mathrm{C}$. Hydrolysis results were measured for reducing sugar levels.

The culture of Saccharomyces cereviceae JCM 3012 was obtained from The Food \& Nutrition Culture Collection (FNCC), Food and Nutrition Centre, Universitas Gadjah Mada. The strain was maintained on YM to keep medium (yeast extract 3 $\mathrm{g} / \mathrm{L}$, malt extract $3 \mathrm{~g} / \mathrm{L}$, peptone $5 \mathrm{~g} / \mathrm{L}$, glucose 10 $\mathrm{g} / \mathrm{L})$ at $4{ }^{\circ} \mathrm{C}$. To carry-out the tests $S$. cerevisiae was grown overnight at $30{ }^{\circ} \mathrm{C}$ on a rotary shaker (INNOVA 44, Incubator Shaker Series, New Brunswick Scientific) at $200 \mathrm{rpm}$, in tubes containing $20 \mathrm{ml}$ YM medium.

Dragon fruit peel which produced on hydrolysis (21 Erlenmeyer treatment with crude enzyme mixture A.niger and T.reese $)$, each were added Saccharomyces cerevisiae at a dose of $10 \%$, then each fermented for 96 hours for bioethanol production. The results of the fermentation treatment were measured by reducing sugar levels with the DNS method to compare sugar levels before and after treatment with $S$. cerevisiae (Jackson and Jayanthy, 2014).

Table 1 shown that reducing sugar from the dragon fruit peel produced after treatment $T$. reesei and A.niger were seen an increase because $T$. reesei and A.niger could produce cellulase enzymes, which can hydrolyze cellulose and hemicellulose into glucose. Enzymatic hydrolysis was regarded today as the most promising approach to liberating fermentable sugars in an energy-efficient way from the carbohydrates found in lignocellulosics in order to produce ethanol (Galbe and Zacchi, 2007).

Fig. 1 shown that reduced sugar decreased during the fermentation process with $S$. cerevisiae. The sugar content in the medium was continuously utilized by $S$. cerevisiae cells for the growth and formation of ethanol. The more reducing sugars used by Saccharomyces cerevisiae cells, the higher ethanol concentration produced and vice versa the less reducing sugars used, the lower the ethanol concentration. The increase in sugar concentration up to a certain level caused the fermentation rate to increase. However, the use of excessive sugar concentration will cause a steady fermentation rate, because the concentration of sugar used beyond the uptake capacity of the microbial cells. Generally, the maximum rate of ethanol production was achieved when using sugars at a concentration of $150 \mathrm{~g} / \mathrm{L}$. The initial sugar concentration also has been considered an important factor in ethanol production. (Zabed et al., 2016)

Fig 2. shown that the levels of bioethanol produced by fermentation are obtained by varying levels of bioethanol. The presence of fermented bioethanol was based on the opinions of Campbell, Reece, J.B., and Nitchel (2003), the results of $S$.

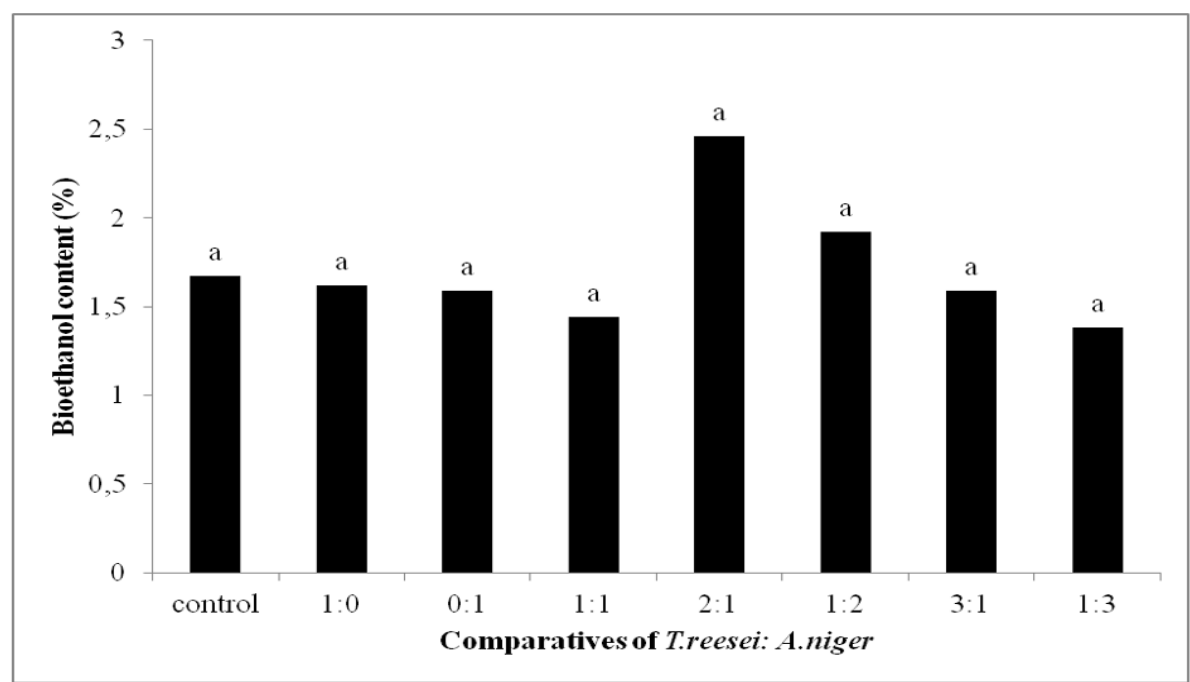

Figure. 2. Bioethanol levels of dragon fruit peel after fermentation using Saccharomyces cerevisiae. The DMRT test ( $>>0.05)$ bioethanol levels were not differ significantly 
cerevisiae metabolism in carbohydrate-based food sources such as sugar, starch, and cellulose are bioethanol. The presence of bioethanol indicates that the $S$. cerevisiae fermentation process is going well. According to the opinion (Wirahadikusumah, 2002) that the decomposition of carbohydrate or cellulose into pyruvate with the help of pyruvate decarboxylase enzyme which is reduced to bioethanol is through the event of glycolysis.

Enzymes from Trichoderma reesei and Aspergillus niger can increase reducing sugar levels $49.68 \%$ in the treatment of T.reesai: A.niger (3: 1) and produce the highest bioethanol level, which is $2.46 \%$ in the treatment of T.reesai: A.niger (2: 1)

\section{ACKNOWLEDGMENT}

The authors would like to thank LPPM Ahmad Dahlan University According to Contract Number: PHB-26/SP3/LPP-UAD/IV/2018.

\section{REFERENCES}

Ali, M. N., Mohd, M. K. and Mohiuddin, M. (2011) 'Ethanol fuel production through microbial extracellular enzymatic hydrolysis and fermentation from renewable agrobased cellulosic wastes, International Journal of Pharma and Bio Sciences, 2(2), pp. 321-331.

Baljit, K., Oberoi, H.S. and Chadha, B.S. (2014) 'Enhanced cellulase producing mutants developed from heterokarytic Asperillus strain', Bioresource Technology, 156, p. 100-107.

Campbell, N.A., Reece, J.B., and Nitchel, L. . (2003) Biology. Fifth Edit. Jakarta: Food Preservation Technology. Jakarta: University of Indonesia Press.

Campbell, N.A.Reece, J.B., and Nitchel, L. . (2003) Biology. Fifth Edit. Jakarta: Food Preservation Technology. Jakarta: University of Indonesia Press.

Chandel, A.K.Chan, E.S, Ravinder R, Lakshmi, N. M, Venkateswar, and Rao L, P. R. (2007) 'Economics of environmental impact of bioethanol production technologies: an appraisal', Biotechnology and Molecular Biology Review, 2(1), pp. 14-32.

David, B. W. (2008) 'Three Microbial Strategies for Plant Cell Wall Degradation', Annals of the New York Academy of Sciences, 1125(1), pp. 289-297. doi: DOI: 10.1196/annals.1419.026.

Dien, B.S., C. M. A. and J. T. . (2003) 'Bacteria engineered for fuel ethanol production: current status. Appl', Microbiol.Biotechnol, 63(1), p. 258-266.
Field, C.B, Campbell, J. E., and Lobell, D. B. (2008) 'Biomass energy: The scale of the potential resource', Trends in Ecology and Evolution, 23(2), pp. 65-72.

Galbe, M. and Zacchi, G. (2007) 'Pretreatment of lignocellulosic materials for efficient bioethano production', Advances in Biochemical Engineering/ Biotechnology, 108(1), pp. 41-65.

Goh, C.S., Tan, K. T., Lee, K. T. and Bhatia, S. (2010) 'Bio-ethanol from lignocellulose: Status perspectives and challenges in Malaysia', Bioresource Technology, 101(13), pp. 4834-4841.

Hambali, E., Siti, M, Halomoan. A.Tambunan, A. Pattiwiri, W. and Hendroko, R. (2007) 'Bioenergy technology', Agro Media Library.

Hahn-Hägerdal, B., Galbe, M., Gorwa-Grauslund, M. F., Lidén, G., and Zacchi, G (2006) 'Bioethanol - the fuel of tomorrow from the residues of today', Trends in Biotechnology, 24(12), pp. 549-556. doi: 10.1016/ j.tibtech.2006.10.004.

Hu. G., Heitmann, J. A., and Rojas, O. J. (2008) 'Feedstock pretreatment strategies for producing ethanol from wood, bark, and forest residues', BioResources, 3(1), pp. 270-294.

Herrera, S. B. (2006) 'about biofuel', Nature Biotechnology, 24, pp. 755-760.

Herrera, S. (2004) 'Industrial Biotechnology-a chance at redemption', Nature Biotechnology, 22, pp. 671-675.

Jackson, B. and Jayanthy, T. (2014) 'Determination of sucrose in raw sugarcane juice by microwave method', Indian Journal of Science and Technology, 7 (5), pp. 566-570.

Jamilah, B, Shu C., E.Sharifah, K. S, Muhammad, D. M. H., and Noranizan, A. (2011) "PhysicoChemical Characteristics Of Red Pitaya (Hylocereus polyrhizus) peel. Malaysia", International Food Research Journal, 18, pp. 279286.

Juhasz, T., K. Kozma, K., and Szengyel, Z. (2003) 'Production of $\beta$-glukosidase in Mixed Culture of Aspergillus niger BKMF 1305 and Trichoderma reesei RUT C30', Food Technology Biotechnolog, 41, pp. 49-53.

Lin, T. (2006) 'Ethanol fermentation from biomass resources: Current state and prospects', Appl. Microbiol. Biotechnol, 69, pp. 627-642.

Lynd, L. R., Liang, X., Biddy, M. J., Allee, A., Cai, H., Foust, T., ... Wyman, C. E. (2017) 'Cellulosic ethanol: status and innovation', Current Opinion in Biotechnology, 45, pp. 202-211. doi: 10.1016/j.copbio.2017.03.008. 
Mehdi, D., Maki, M, Leung, K.T. and Mao, C. (2010) 'Cellulase activities in biomass conversion: measurement methods and comparison', Critical Reviews in Biotechnology, 30, p. 302-309.

Merino, S.T. and Cherry, J. (2007) 'Progress and challenges in enzyme development for biomass utilization'.

Safaria, Selviza., N. I. dan T. A. Z. (2013) 'Effectiveness of Cellulase Enzyme Mixtures of Aspergillus niger and Trichoderma reesei in Hydrolyzing Coconut Fiber Substrate 'Equatorial Chemistry Journal, 2.

Sakai, S., Tsuchida, Y., Nakamoto, H., Okino, S., Ichihashi, O., Kawaguchi, H., Y. H. (2007) 'Effect of lignocellulose-derived inhibitors on growth of and ethanol production by growth arrested Corynebacterium glutamicum R', Applied and Environmental Microbiology, 73(7), pp. 2349-2353.

Sri Winarsih, Bambang, D. A, Agustin, K.W., and Elok, Z. (2014) 'The increasement of rice straw hydrolysis using blend crude cellulose enzyme from Trichoderma reesei and Aspergillus niger', Research and Reviews in BioSciences, 9(2), pp. 41-44.

Schubert, S. (2006) 'Can biofuels finally take centre stage', Nature Biotechnology, 24(7), pp. 777-784.

Sunkyu, P., Baker, J.O. Himmel, M.E. Parilla, P.A. and Johnson, D.K.. (2010) 'Cellulose crystallinityy index: measurement techniques and their impact on interpreting cellulase performance', Biotechnology. Biofuels, 3, p. 1-10.

Szendefy, J.; Szakacs, G. and Christopher, L. (2006) "Potential of solid-state Fermentation Enzymes of Aspergillus in Biobleaching of Paper Pulp", Enzymes and Microbial Technology, 39, pp. 1354-1360.
Vandana, R. and Anahit, D., (2014) 'Eckard and Philip Teller, Birgitte K. Ahring. On-site enzymes produced from Trchoderma reesei RUTC30 and Aspergillus saccharolyticus for hydrolysis of wet expoded corn stover and loblolly pine', Bioresource Technology, 154, p. 282289.

Veeresh, J. and Wu J.C.. (2014) 'Microbial cellulases: Engineering, production and applications', Renewable Sustainable Energy Review, 33, p. 188203.

Vertès, A. A., Inui, M., and Yukawa, H. (2006) 'Implementing biofuels on a global scale', Nature Biotechnology, 24, pp. 761-764.

Wirahadikusumah, M. (2002) Biochemical Metabolism of Energy, Carbohydrates, and Lipids. Bandung: ITB Bandung Publisher.

Wyman, C. (1999) 'Opportunities and Technological Challenges of Bioethanol', in Presentation to the Committee to Review the $\mathrm{R}$ and D Strategy for Biomass -Derived Ethanol and Biodiesel Transportation Fuels. Beckman Center, Irvine, California.

Zabed, H., Sahu, J. N., Boyce, A. N., and Faruq, G. (2016) 'Fuel ethanol production from lignocellulosic biomass: An overview on feedstocks and technological approaches', Renewable and Sustainable Energy Reviews. doi: 10.1016/j.rser.2016.08.038. 